\title{
HUBUNGAN KARIES GIGI IBU DAN BALITANYA DI TIGA KECAMATAN KABUPATEN JEMBER
}

\author{
(RELATION OF MOTHER'S CARIES WITH THEIR BABY IN THREE \\ SUBDISTRICT OF JEMBER DISTRICT)
}

\author{
Ristya Widi Endah Yani \\ Departemen Ilmu Kesehatan Gigi dan Mulut Masyarakat/Pencegahan \\ Fakultas Kedokteran Gigi, Universitas Jember \\ Jl. Kalimantan 37 Jember \\ E-mail: ristya_widi@yahoo.com
}

\begin{abstract}
Mothers health and health knowledge have big influences on their children and families health, therefore preschoolers oral health is greatly affected by their mothers. Mothers effects which turned out to be the risk factors for preschoolers caries are caries, oral hygiene, knowledge, life styles and behaviors mothers toward dental treatments. This research aims to analyze the relation between mothers and her preschoolers children caries. This study is an observational analitic with cross sectional approach which was conducted to mothers and her preschoolers children caries in three sub districts in Jember. Sample taken of 84 mothers and 84 her preschoolers children (4-5 years old) was done purposively. Variables of the study are mothers caries (DMF-T index) and preschoolers caries (def-t index). To find out the relationship of mothers and her preschoolers children caries in the three districtsof Jember Regency with Spearman correlation test. The results showed mean of mothers caries was 3,82 $\pm 1,59$ andher preschoolers children cariesis $4,07 \pm 2,07$. There was correlation between mothers and their preschoolers children caries in the three districts of Jember Regency $\left(\mathrm{p} \leq \alpha_{(0,05)}\right)$ with correlation coefficient is $+0,6$. In conclusion, there is a correlation between mothers and their preschoolers children caries, the higher mothers caries, their preschoolers children caries too.
\end{abstract}

Key words: mothers caries, preschoolers children caries

\begin{abstract}
Abstrak
Kesehatan dan pengetahuan kesehatan ibu memiliki efek yang besar terhadap kesehatan balita dan keluarganya, begitu juga dengan kesehatan rongga mulut balita sangat dipengaruhi oleh ibunya. Faktor-faktor yang merupakan faktor risiko terjadinya karies balita adalah karies, oral hygiene, pengetahuan dan sikap ibu terhadap perawatan gigi serta gaya hidup ibu. Tujuan penelitian ini adalah untuk mengetahui hubungan karies ibu dengan karies balitanya. Metode penelitian adalah observasional analitik dengan pendekatan cross sectional pada ibu dan balitanya di 3 kecamatan Kabupaten Jember. Pengambilan sampel 84 ibu dan 84 balitanya usia 4-5 tahun dilakukan secara purposif. Variabel yang diteliti adalah karies gigi ibu (DMF-T indeks) dan balita (def-t indeks). Untuk melihat hubungan karies gigi ibu dan balitanya di tiga kecamatan Kabupaten Jember dilakukan uji korelasi Spearman. Hasil penelitian menunjukkan rata-rata karies gigi ibu 3,82 $\pm 1,59$ dan karies gigi balita 4,07 $\pm 2,07$. Terdapat hubungan karies gigi ibu dan balitanya di tiga kecamatan Kabupaten Jember $\left(\mathrm{p} \leq \alpha_{0,05}\right)$ dengan koefisien karelasi sebesar $+0,6$. Sebagai kesimpulan, terdapat hubungan karies gigi ibu dengan balitanya, semakin tinggi karies ibu semakin tinggi pula karies balitanya.
\end{abstract}

Kata kunci: karies gigi ibu, karies gigi balita

\section{PENDAHULUAN}

Masalah kesehatan gigi dan mulut dengan prevalensi tertinggi di dunia adalah karies gigi, yang mana penyakit ini secara signifikan berdampak sosial. Karies gigi mempengaruhi $60-90 \%$ anak usia sekolah dan sebagian orang dewasa. ${ }^{1,2}$ Prevalensi ka- ries gigi di Indonesia mencapai sekitar 90\% dari 238 juta penduduk, dan $76,5 \%$ nya adalah anak usia dibawah 15 tahun. Pada penelitian Siagian ditemukan 95\% anak Sekolah Dasar mempunyai kesehatan gigi dan mulut yang buruk dan menderita karies gigi. ${ }^{3}$ Oleh karena itu karies gigi merupakan penyakit dengan prevalensi yang cukup tinggi di Indonesia. 
Kesehatan dan pengetahuan kesehatan ibu berpengaruh besar terhadap kesehatan anak dan keluarganya. Secara umum, semua anggota keluarga dapat mempengaruhi tingkah laku anak, akan tetapi pengaruh ibu adalah yang paling dominan karena ibu memberikan perawatan primer anak dan berperan penting dalam tumbuh kembang serta pembentukan karakter anak. ${ }^{4}$ Kesehatan gigi anak sangat dipengaruhi oleh pengetahuan dan sikap ibu dalam menjaga kesehatan gigi. Ibu yang tidak peduli dengan kesehatan gigi dan mulutnya akan berakibat terhadap buruknya kesehatan gigi anaknya, sehingga sangat memungkinkan adanya hubungan antara karies gigi ibu dengan karies gigi balitanya.

Selain pengetahuan dan sikap ibu dalam menjaga kesehatan gigi, seorang ibu dapat mempengaruhi kondisi kesehatan gigi anaknya melalui penularan bakteri Streptococcus mutans dari ibu ke anaknya. Penularan penyakit karies gigi dapat secara horizontal maupun vertikal. ${ }^{5}$

Tujuan penelitian ini adalah untuk mengetahui hubungan antara karies gigi ibu dengan karies gigi balitanya.

\section{BAHAN DAN METODE}

Penelitian observasional analitik dengan pendekatan crosssectional dilakukan pada ibu dan balitanya (4-5 tahun) di 7 posyandu dari 3 kecamatan (Wuluhan, Rambipuji, Ledokombo) Kabupaten Jember. Secara purposif diambil sampel 84 orang ibu dan 84 orang balitanya. Variabel yang diteliti adalah karies gigi ibu yang diukur dengan indeks DMF-T dan karies gigi balita dengan indeks def-t. Untuk melihat hubungan karies gigi ibu dan balitanya di tiga kecamatan Kabupaten Jember dilakukan uji korelasi Spearman.

\section{HASIL}

Nilai minimum karies gigi ibu adalah 2 , nilai maksimum adalah 8 , rata-rata adalah 3,82 $\pm 1,59$ dan varians sebesar 2,53. Nilai minimum karies gigi balita adalah 2 , nilai maksimum adalah 10 , rata-rata adalah 4,07 $\pm 2,07$ dan varians sebesar 4,28 (Tabel 1).

Tabel 1. Nilai mean dan varians karies gigi ibu dan balita

\begin{tabular}{lccccc}
\hline Variabel & $\mathrm{n}$ & Minimum Maksimum & Mean \pm SD & Varians \\
\hline DMF-T & 84 & 2 & 8 & $3,82 \pm 1,59$ & 2,53 \\
\hline def-t & 84 & 2 & 10 & $4,07 \pm 2,07$ & 4,28 \\
\hline
\end{tabular}

Hasil analisis korelasi Spearman menunjukkan bahwa rerata karies gigi ibu berhubungan dengan karies balitanya ( $p$-value $=0,00$ ) dengan koefisien korelasi sebesar $+0,6$.

\section{PEMBAHASAN}

Hasil penelitian menunjukkan bahwa rerata karies gigi ibu 3,82 $\pm 1,59$ dan rerata karies gigi balita 4,07 $\pm 2,07$ (termasuk kategori sedang). Terdapat hubungan karies ibu dengan balita, semakin tinggi karies ibu maka semakin tinggi pula karies balitanya (hal ini dibuktikan dengan $p$-value $=0,00$ dan koefisien korelasi sebesar $+0,6$ ). Kesehatan dan pengetahuan kesehatan ibu berpengaruh besar terhadap kesehatan anak dan keluarganya. Ibu merupakan figur penting di keluarga dan menjadi pelaksana utama dalam kegiatan keluarga. Meskipun semua anggota keluarga dapat memberikan efek bagi tingkah laku anak, pengaruh ibu tetap yang paling penting, karena ibu memberikan perawatan primer terhadap anak dan memainkan peran penting dalam tumbuh kembang dan pembentukan pola karakter anak. ${ }^{4}$ Kesehatan rongga mulut seorang anak sangat dipengaruhi oleh pengetahuan dan sikap ibunya Faktor-faktor ibu yang merupakan faktor risiko terjadinya karies pada anak adalah tingkat karies ibu, oral hygiene ibu, dan juga faktor sosial ekonomi keluarga. ${ }^{6}$ Orang tua terutama ibu memegang peran kunci dalam memelihara kesehatan balita. Ibu tidak hanya berperan sebagai fasilitator dalam membersihkan mulut balita, tapi juga sebagai inisiator perilaku menjaga kesehatan mulut balita. ${ }^{7,8} \mathrm{Ibu}$ sebagai pengasuh utama harus dapat membantu dalam merawat kesehatan mulut balita. Perilaku orang tua menentukan status kesehatan gigi dan mulut balita, karena itu orang tua harus cukup pengetahuan tentang pencegahan penyakit gigi dan mulut, hal ini harus dilakukan selama dua tahun pertama kehidupan balita yang merupakan periode yang paling penting. ${ }^{9}$

Beberapa penelitian sebelumnya menunjukkan bahwa pengetahuan seorang ibu sangat berpengaruh terhadap kesehatan gigi anak-anaknya, yang mana seorang ibu dengan latar belakang pendidikan yang tinggi akan memiliki pengetahuan kesehatan gigi yang lebih baik. ${ }^{10} \mathrm{Hal}$ ini juga mendukung adanya hubungan yang kuat antara skor def-t anak dengan tingkat pengetahuan ibu. Insidens karies akan semakin tinggi pada anak-anak dengan ibu berpengetahuan rendah. Hal ini dikarenakan pengetahuan yang tinggi pada ibu akan meningkatkan kesadaran dan pemahaman akan masalah kesehatan, khususnya kesehatan rongga mulut. Ibu dengan tingkat pengetahuan yang baik akan mengajarkan anaknya untuk menggunakan sikat dan pasta gigi, mengajarkan waktu yang tepat untuk menggosok gigi dan juga membatasi konsumsi makanan bergula bagi anak-anaknya. ${ }^{4}$ Sehingga semakin baik tingkat pengetahuan 
seorang ibu maka akan semakin baik pula tingkat kesehatan gigi dirinya sendiri dan juga anak-anaknya.

Sikap ibu terhadap perawatan gigi juga menjadi indikator penting terhadap kesehatan gigi anakanaknya. Seorang ibu yang rutin kontrol ke dokter gigi akan mengajak anaknya ke dokter gigi sedini mungkin yaitu pada usia pra-sekolah, dan check-up untuk mengkontrol kesehatan gigi anaknya. Beberapa penelitian membuktikan bahwa seseorang yang rutin melakukan kontrol ke dokter gigi memang sudah memiliki kebiasaan tersebut sejak usia dini. Sehingga kebiasaan check-up 6 bulan sekali memang harus dibentuk dari usia dini, dan kebiasaan tersebut sangat bergantung dengan sikap ibu. ${ }^{11}$

Selain itu, pengalaman dan tingkat kecemasan seorang ibu terhadap perawatan gigi juga berakibat pada kesehatan gigi anaknya. Seorang ibu yang tidak pernah melakukan perawatan gigi dan merasa takut untuk berobat ke dokter gigi, akan mengakibatkan munculnya stimulus rasa takut juga ke anaknya. Munculnya phobia dengan perawatan gigi pada ibu sangat mempengaruhi kooperatifan seorang anak. ${ }^{4}$ Sehingga jika seorang ibu memiliki rasa takut terhadap perawatan gigi sangat memungkinkan selain mengakibatkan buruknya skor DMF-T dirinya sendiri dan juga skor def-t anaknya.

Kebiasaan hidup (life style) seorang ibu juga sangat berpengaruh terhadap kesehatan gigi anaknya. Seorang ibu akan memperkenalkan dan memberkan jenis makanan terhadap anak-anaknya. Kebiasaan buruk konsumsi makanan bergula yang berlebihan terbentuk dari usia dini yang biasanya banyak diajarkan oleh seorang ibu, sehingga akan meningkatkan risiko insidensi karies gigi anak-anaknya. ${ }^{10}$

Sikap orang tua dalam menjaga kesehatan giginya berhubungan dengan perilaku menjaga kesehatan gigi anaknya. Beberapa penelitian menyimpulkan, keyakinan dan sikap orang tua terhadap kesehatan gigi dan mulut berkaitan dengan perkembangan karies balita. Beberapa kondisi seperti pengetahuan, sosial budaya dapat mempengaruhi kepercayaan dan sikap. Studi cross-sectional dengan desain prospektif dan random sampling sebanyak 523 balita usia 5 tahun di Norwegia dengan tujuan menjelaskan keadaan karies balita dan mempelajari hubungan antara pengalaman karies dengan karakteristik keluarga seperti pendidikan, latar belakang budaya orangtua dan perilaku menjaga kesehatan gigi, menunjukkan adanya hubungan antara pengalaman karies orang tua, pendidikan orang tua, kebiasaan menyikat gigi, frekuensi konsumsi gula, perilaku menyikat gigi, akses untuk perawatan gigi, riwayat penyakit gigi dikaitkan dengan kejadian karies balita. ${ }^{11}$

Tingginya karies ibu berhubungan dengan me- ningkatnya karies balita juga disebabkan adanya penularan bakteri Streptococcus mutans dari ibu ke anak baik melalui transmisi vertikal maupun horizontal, ${ }^{5}$ sehingga ibu dapat dianggap sebagai natural source bagi infeksi anaknya. Transmisi horizontal menular melalui kontak dengan saliva yang terkontaminasi sputum dan darah yang terinfeksi. Beberapa penelitian menunujukkan bahwa anak-anak lebih beresiko mendapatkan infeksi bakteri Streptococcus mutans jika saliva ibunya terdapat Streptococcus mutans yang tinggi. Resiko penularan Streptococcus mutans ibu ke anaknya disebabkan adanya tranmisi horizontal melalui kontak langsung antara saliva ibu dengan saliva anak dan juga kebiasaan berbagi makanan antara ibu dan anak. ${ }^{12}$ Transmisi vertikal didapatkan melalui transmisi genetik ibu ke anak. Tranmisi ini dapat melalui air susu ibu, cairan tubuh seperti saliva ibu, dan plasenta. Penelitian isolasi strain bakteri dari ibu ke anak menunjukkan kesamaan, yaitu adanya kesamaan kromosom atau plasmid DNA.Hal ini menunjukkan bahwa ibu merupakan sumber utama transmisi Streptococcus mutans anaknya dan frekuensi terjadinya tranmisi vertikal lebih banyak ditemukan pada ibu hamil. ${ }^{5}$

Sebagai kesimpulan, terdapat hubungan antara karies gigi ibu dengan karies gigi balita, semakin tinggi karies ibu maka semakin tinggi pula karies balitanya

\section{Daftar Pustaka}

1. Petersen PE, Denis, Bourgeois HO, Estupinan-Day $\mathrm{S}$, Ndiaye $\mathrm{C}$. The global burden of Oral Diseases and Risks to Oral Health. Bulletin of the World Health Organization 2005; 83: 661-669.

2. Dixit LP, Shakya A, Shrestha M, Shrestha A. Dental caries prevalence, oral health knowledge and practice among indigenous chepang school children of nepal. BMC Oral Health 2013; 13(20): 1-5.

3. Rahmawati I, Hendratini J, Priyanto A. Prilaku kesehatan gigi dan mulut pada anak sekolah dasar. Berita Kedokteran Masyarakat 2011; 27(4).

4. Raj R. Vaibhav V. Maternal factors and child oral health. IJHSR 2012; 2(8).

5. Javed M, Chaudhry S, Buut S, Ijaz S, Asad R, Awais F, et al. Transmission of streptococcus mutans from mother to child. Pakistan Oral and Dental Journal 2012; 32(3).

6. Retnakumari N, Cyriac G. Chilhood caries as influenced by maternal and child characeristics in preschool children of keralaan epidemology study. Contemporary Clinical Dentistry2012; 3(2).

7. Simin Z, Mohebbi SZ, Virtanen JI, Murtomaa H, Golpayegani MV, Vehkalahti MM. Mothers as facilitators of oral hygiene in early childhood. International Journal of Paediatric Dentistry 2008; 18 : 48-55. 
8. Prakash P, Subramaniam P, Durgesh BH, Konde S. Prevalence of early childhood caries and associated risk factors in preschool children of urban bangalore, India: A Cross-Sectional Study. European Journal of Dentistry 2012; Vol. 6(2): 141-152.

9. Oredugba F, Agbaje M, Ayedun O, Onajole A. Assessment of mothers' oral health knowledge: Towards Oral Health Promotion for Infants and Children. Health 2014; 6: 908-915.

10. Verma S, Kalpana B, Sinhal S. Correlation between early chilhood caries and maternal caries status and influence of preventive educational counseling on children`s s. mutans level. Universal Research Journal of Dentistry 2013; 3(1).

11. Wigen T, Wang N. Parental influences on dental caries development in preschool children. An Overview with Emphasis on Recent Norwegian Research. Norsk Epidemiologi 2012; 22(1).

12. Graham R, Montaque. The impact of maternal influences on early chilhood dental caries. Theses and Disertations. Virgina Commonwealth University 2012. 